\title{
Neurometric evaluations on the brain of the opossum (didelphys marsupialis cancrivora (linnaeus 1758) - a case for cognitive skill -brain development capacity
}

\author{
SAMUEL, O. M. ${ }^{*}$, OLOPADE, J. O. ${ }^{2}$ and ONWUKA, S. K. ${ }^{3}$ \\ ${ }^{1}$ Cranio-facial and maxillo-facial Anatomy, Depatment of Veterinary Anatomy, \\ University of Agriculture Makurdi, Nigeria \\ ${ }^{2}$ NeuroAnatomy unit, Department of Veterinary Anatomy, University of Ibadan, Nigeria \\ ${ }^{3}$ Head Gross Anatomy, Department of Veterinary Anatomy, University of Ibadan, Nigeria \\ *E-mail: walesamuell0@gmail.com
}

\begin{abstract}
Introduction: The Opossum is a marsupial related wild life species belonging to the order Didelphimorphia. They inhabit the swampy forest zones in Nigeria but could inhabit drier regions. Some are arboreal and digitigrades, characterized by long bare tails and opposable thumbs modified for climbing and grasping respectively, they are known to be deficient in comparative sociality, peculiar brain morphology and a short life span. Our aim was to correlate through macro-neuromorphometry as well evaluate for the influence of head and brain weight, sex, adaptation, and behavioral ecology on the brain dimensions in comparison with other marsupials. Method: This study utilized thirteen animals (didelphys marsupialis cancrivota) consisting of four (6) males and seven (7) females and employing statistical methods in making inferences among the categories. Results: The mean overall head weight was $256.17 \pm 54.11 \mathrm{~g}, 250.60 \pm 51.62 \mathrm{~g}$ for females and $269.16 \pm 139.22 \mathrm{~g}$ for males, the whole brain weight was $30.43 \pm 10.19 \mathrm{~g}$. The brain $/$ head weight ratio was $0.05 \pm 0.02$ while the maximum cerebral diameter, length and height were $46.97 \pm 13.84 \mathrm{~mm}, 48.01 \pm 19.72 \mathrm{~mm}$ and $30.48 \pm 2.90 \mathrm{~mm}$. cerebellar weight was $1.81 \pm 1.09 \mathrm{~g}$, and the cerebellar height and width were $2.39 \pm 0.38 \mathrm{~mm}$ and $2.44 \pm 1.59 \mathrm{~mm}$ respectively, cerebrum/ whole brain length index was $0.86 \pm 0.04 \mathrm{~mm}$ while mean endo-cranial volume was $19.75 \pm 30.11 \mathrm{mls}$. The sexually dimorphic variables include whole brain length $(59.87 \pm 9.56 \mathrm{~mm}$ and $57.12 \pm 12.01 \mathrm{~mm})$, cerebral length $(49.93 \pm 10.17 \mathrm{~mm}$ and $41.12 \pm 15.57 \mathrm{~mm})$ and cerebral diameter $(35.91 \pm 13.55 \mathrm{~mm}$ and $43.54 \pm 29.96 \mathrm{~mm})$ for females and males respectively, suggesting better encephalization in females of this species compared to the males. Also, dimorphic parameters function for purposes such as predatory instincts, nursing of the young, spatial orientation, migrations and ecologic adaptations. Conclusion: In addition, this investigation suggests the enhanced possibility of cerebro-vascular accident in this species partly due to the cerebral length and height ratio in relation to the endo-cranial volume and shape in the likelihood of shorter lifespan in the males.
\end{abstract}

Keywords: macroneuromorphometry, opossums, didelphys marsupialis cancrivora, encephalisation variables, intelligence.

\section{Introduction}

'This opossum belongs to the Order Didelphimorphia as described by (MARSHAL, 1990) and the family Didelphidae by GRAY (2009). In Nigeria, this wild-life species could be found in the swampy areas of the rain forest zones, their population reduces as the climate alters in the initial borders of the guinea savannah (the semi-arid region), but rarely found beyond this region (HAPPOLD, 1987). They are scansorial, ambulatory and digitigrades. This group converges on rodents and enjoys wide first bio-geographic radiations around North America, South America, then a second from Australia to Africa as mentioned by (LES and COCKBURN, 1985). They are presently classified as one of the endangered species of the world particularly in Nigeria where the predators does not exclude man, hunted for meat as well as by bobcats, raccoons and hawks (ZORILLINAB, 2008). Recent observations in Nigeria portrayed them as invasive. The body length is about $51 \mathrm{~cm}$ with a total body weight between 4-6kg (NOWAK, 1999). This species with arboreal specializations inhabits other ecological environments the climate notwithstanding. Comparatively they are larger than the African Cane rat (Thryonomys swinderianus) (AJAYI, 1974; APLIN and ARCHER, 1987; SEMENDEFERRI, ARMSTRONG, SCHLEICHER et al., 2002) and a typical heavy body set similar to cats excepting in the poor social development (GRAY, 2009).

There is no literary information on the brain macromorphology or neurobiology of this species of wild life in comparative morphology to other animals of similar ecohabitat and body size. This, to the best our knowledge has not been prior reported in Nigeria. The species has been found to exhibit heterogenecity in some distinguishing skeletal morphological features relating to the varying eco-diversity of the locations they were found. The aim of this survey is 
to conduct a neurometric investigations of the brain of the Opossum (Didelphys marsupialis cancrivora) taken from their natural environment in an effort to provide baseline data for neurobiological research, taxonomic classifications, ecomigation surveillance and paleontology of members of the order didelphymorphia (MARSHAL, 1990).

\section{Materials and Methods}

The study utilized a total of eleven (11) animals, consisting of seven (7) females and four (4) males, out of which 3 (three) were the young ( 2 (two) females and 1 (male) identified by the pelage and dental eruptions (GIULIA, ZOTTI, AGNESSI et al., 2009) collected from peasant hunters. Total of thirteen (13) measurements were taken

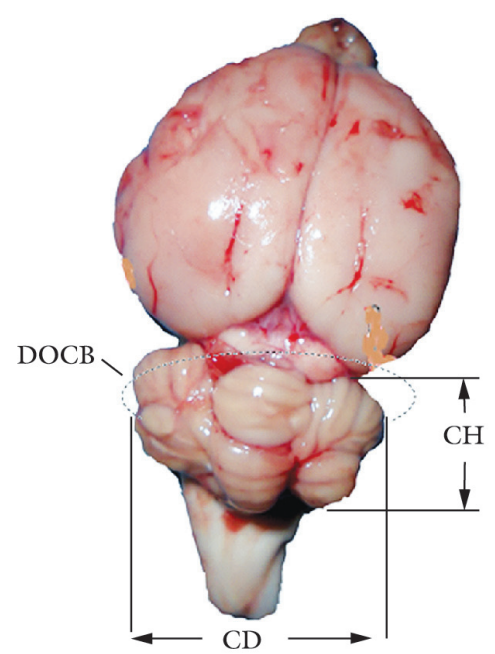

DOCB - Distance over cerebellum

$\mathrm{CH}$ - Cerebellar height CD - Cerebellar diameter

Figure 1. Dorsal view of Adult Opossum (Didelphys marsupialis cancrivora) brain.

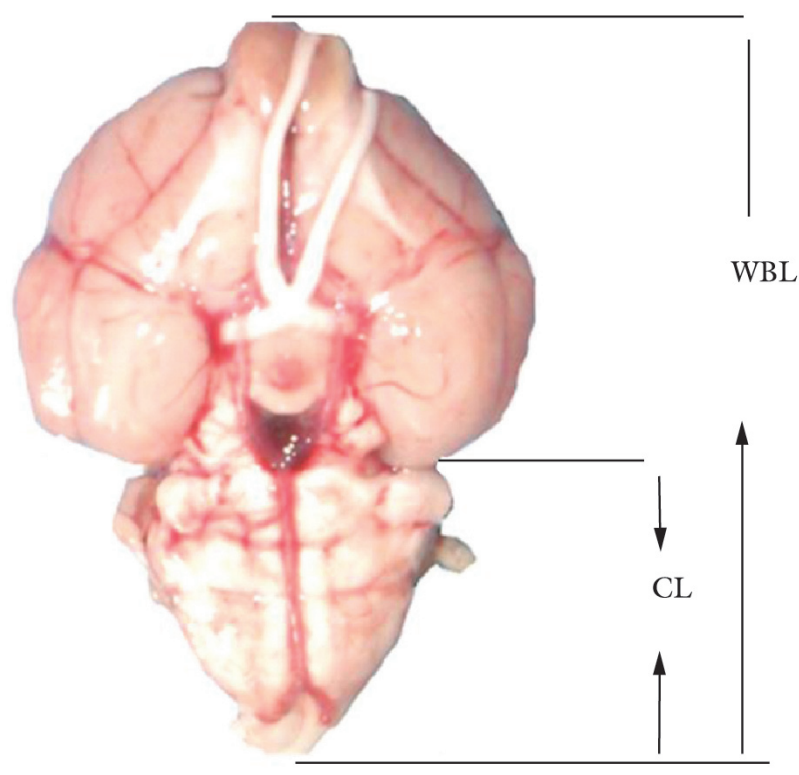

Figure 2. Ventral view Adult Opossum (Didelphys marsupialis cancrivora) brain. on the head, brain and skull with some assessed landmarks depicted on Figures 1-4.

These harvested heads were decapitated at the atlantooccipital region of the neck, they were then stored in the freezer at a constant temperature of $-20{ }^{\circ} \mathrm{C}$. The thawed out frozen heads were weighed on an electronic high precision strain guage sensor, digital weighing scale and (CMY WEIGH i201). Repeated weighing on ice was carried out and the mean recorded (GIULIA, ZOTTI, AGNESSI et al., 2009).

The heads were grouped on head weight basis first; between $0-210 \mathrm{~g}, 211-300 \mathrm{~g}$ and above $301 \mathrm{~g}$ and above, the brain weight categories were between $0-7.00 \mathrm{~g}$, between $7.00 \mathrm{~g}-14.00 \mathrm{~g}$ and those above $14.00 \mathrm{~g}$. A final grouping was on gender basis (SAMARANCH and GONZALEZ, 2000).

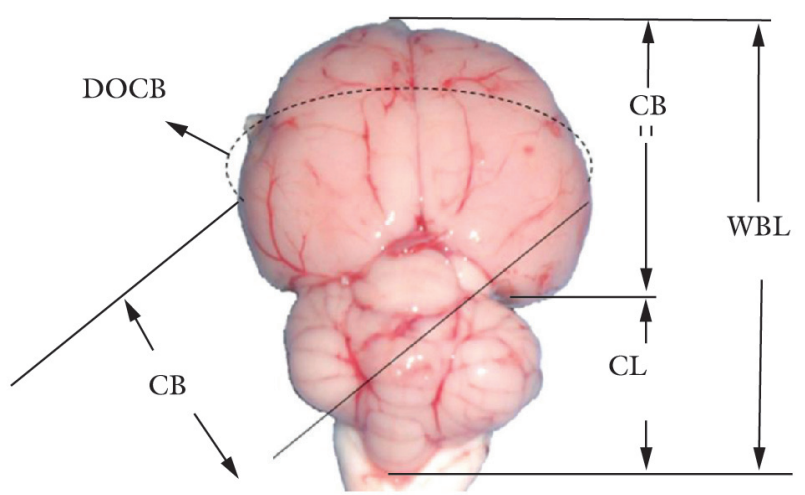

Figure 3. Dorsal view Baby Opossum (Didelphys marsupialis cancrivora) brain.

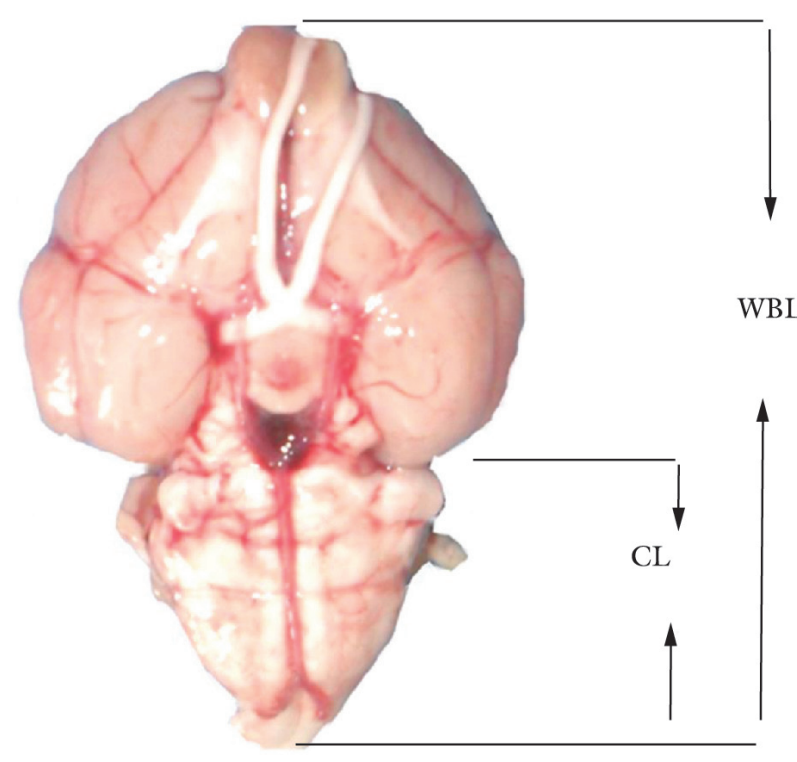

WBL - Whole brain length CL - Crebellar length Cerebe length

Figure 4. Ventral view Baby Opossum (Didelphys marsupialis cancrivora) brain. 


\subsection{Neurometric measurements}

The neocortex with their absolute magnitude were recorded as the brains were removed from the skulls and measured after the frozen heads were splitted sagittally with the aid of an electric band saw dividing the head rostrocaudally into two neat halves after an initial topographical mapping and marking from the philthrum to the dorsal occipital protuberance. The brains were first teased out of each half of the skull, preserved in $0.9 \%$ normal saline for about 60 seconds and weighed wholly, thereafter both cerebrum and cerebellum were weighed separately after careful separation from the brain stem and peduncles and all weighed as earlier recorded. Neurometric readings were recorded using a linear electronic caliper having a capacity of $150 \mathrm{~cm}$, and a precision value of $0.1 \mathrm{~mm}$. The linear variables considered are as listed in the morphometric definitions of variables measured.

\subsection{Skull maceration and neurocranial volume assesments}

To obtain the neurocranial volumes, the heads were macerated according to the method described by (OLOPADE, 2006). Each splitted skull halves was held together with an adhesive, the various foramina of the skull except the foramen magnum were sealed off with plasticine to prevent leakage, fine rice grains was then poured to fill the cranial cavity to the brim of the foramen magnum. Each fillings per skull was poured into a graduated measuring cylinder of $300 \mathrm{cc}$ capacity, this procedure was repeated thrice for each macerated skull and average values recorded.

\subsection{Morphometric definitions of variables measured}

- HWt - Head weight measured in grammes.

WBWt - Whole brain weight- Measured in grammes after sagittal splitting of the skull.

- CBL - Cerebral length- Measured from the most rostral portion of the frontal lobe along the median longitudinal fissure to the base of the occipital lobe of the brain.

- CBD - Cerebral diameter- Maximum width Measured linearly from the most lateral part, lateral to the lateral sulcus of the temporal lobe on one side across an horizontal transverse plane to the other hemisphere's temporal lobe.

- CBH - Cerebral height- Maximum height measured from the base of the diencephalon between the hemispheres in a vertical plane to the dorsal of the cerebral cortex (with the brain resting on a horizontal surface).

- DOCB - Distance over cerebrum- Maximum distance measured with a thread from the base of the temporal lobe on one side with the brain resting on a horizontal surface) over the parietal to the temporal lobe of the other hemisphere.

- DUCB - Distance under cerebrum- Maximum distance with a thread from the base of the temporal lobe on one side (with the brain resting on a horizontal surface) under the brain stem (detached) to the temporal lobe of the other hemisphere.
- CWt - Cerebellar weight- Measured in grammes without the rostral, middle and lateral cerebelar peduncles.

- CH - Cerebellar height- Maximum height measured on a vertical plane passing through the median fissure to the highest point of the vermis cortex.

- CD - Cerebellar diameter- Maximum distance from the most lateral part of the cerebellar hemisphere measured through a transverse horizontal plane passing through the median fissure to a similar opposite point,

- WBL - Whole Brain length-Dorsal measurement (with the brain resting on a horizontal plane) from the most anterior portion of the cerebrum to the caudal base of the cerebellum (medullary vella),

- WBWt/HWt - Whole brain weight / Head weight index.

- CBL/WBL - Cerebral length//Whole brain length index.

\subsection{Method of data analysis}

The values obtained in this study were analysed using a 2-way ANOVA using the graph pad prism 5.04 statistical package, (Kepler Meier percentage survival and death graphs), data was presented as mean $\pm S$.D for gender, head and brain weight categories.

\section{Results}

\subsection{Two-way ANOVA}

Head and brain weight interaction is highly significant $(\mathrm{P}<0.0001)$ with the row factors. Interaction accounts for approximately $3.35 \%$ of the total variance.

The graph exposes a highest/lowest survivability among lowest/highest brain weight groups and attempts to show some brain morphological data (CBD and $\mathrm{CH}$ ) higher in the $\leq 7.00 \mathrm{~g}$ group and lower among 7.00-14.00g brain mass group.

Head weights accounts for approximately $1.13 \%$ while row factor $79.08 \%$ of the total variance. The effect is considered extremely significant $(\mathrm{P}<0.0001)$

Interactionbetween the head weights above $301 \mathrm{~g}$, brain weights above $(14 \mathrm{~g})$ and all parameters assessed accounts for approximately $1.31 \%$ of the total variance, the interaction is considered extremely significant $\mathrm{P}$ value is $<0.0001$.

\section{Discussion}

Though there were no significant differences in the overall parameters assessed between the sexes, the resulting confidence interval is wide due to large standard deviations as observed from the samples reflecting heterogeneity among the sample subjects. The mean head weight of the females in this study is lower than that of the males; $250 \pm 51.62 \mathrm{~g}$ to $269.16 \pm 136.99 \mathrm{~g}$, their whole brain weight is higher than the males. Metric measurements WBL, CBL and CBD are significantly higher in these didelphid females. The relative brain weight to head weight of $1 / 8$ is higher in this species than what obtains in the mouse and man which is approximately $1 / 40 \mathrm{i}$.e brain-to- body mass, (since head weight approximates about a tenth of the body mass) (ABE, 1989; AJAYI, 1974; ANDROUKAKI, FATAEA, HART et al., 2002; KHULENBECK, 1973). The males have a higher cerebellar height $(\mathrm{CH})$ of $2.40 \mathrm{~mm}$ than the females 
$2.38 \mathrm{~mm}$ and $(\mathrm{CD})$ of $2.54 \mathrm{~mm}$ but smaller cerebellar length (CBL) suggesting an empirical morphologic dimorphism along gender lines (Table 1). Females in breeding seasons or pregnancy may have a higher brain/head weight index (GRAY, 2009).

All metric measurements of heads assessed to be less than $200 \mathrm{~g}$ weight was found to be lower than any of the other two groups representing the linear function or positive correlation of this index and body weight (KHULENBECK, 1973; EISENBERG and WILSON, 1981). Although the relative allometric magnitude of some brain parts showed strong individual differences (Figure 5) Semendeferi, Armstrong, Schleicher et al. (2002), such parameters as the WBWt and the $\mathrm{CBH}$ among the heads of the didelphids remained constant. The former is a dependent variable of the cephalization factor and body weight. Recent research has shown that whole brain weight (absolute or relative) is a better measure of cognitive abilities than brain-body mass (GERHARD and DICKE, 2005; HART, HART, MCCOY et al., 2007; HAIER, JUNG, YEO et al., 2004). This opossum species has been observed to be deficient in commissural fibres and lack a gross communication (corpus callosum) between the brain hemispheres (NOWAK, 1999).

$\mathrm{CBH}$ value peaks at $42.03 \pm 24.60 \mathrm{~mm}$ within the head weight category with the largest sample size with a mean head weight $239.75 \pm 36.36 \mathrm{~g}$, this parameter was not significantly different along gender lines (Table 1).

All of the aerial insectivore and foliage-gleaning species belong to the less encephalized Chiropterans, nuclear DNA retrotransposon site and branching sequence analysis has

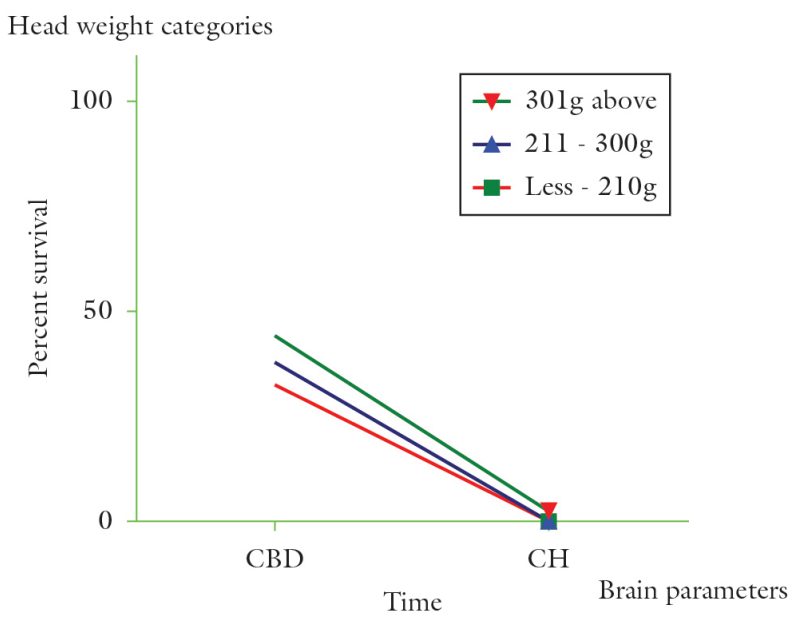

Figure 5. Percentage Survival curve of brain weight categories.

Table 1. Brain and head weight categories between the sexes expressed as mean \pm standard deviations.

\begin{tabular}{|c|c|c|c|c|c|c|c|c|}
\hline \multirow{2}{*}{$\begin{array}{l}\text { Variables } \\
\mathrm{S} / \mathrm{N}\end{array}$} & \multirow{2}{*}{$\begin{array}{c}\text { Female } \\
\mathbf{n}=7\end{array}$} & \multirow{2}{*}{$\begin{array}{l}\text { Male } \\
n=6\end{array}$} & \multicolumn{2}{|c|}{ Head weight categories } & \multirow{2}{*}{$\begin{array}{c}\text { Mean } \pm \text { S.D } \\
\mathrm{n}=4 \\
30 \mathrm{lg}>\end{array}$} & \multicolumn{2}{|c|}{ Brain weight categories } & \multirow{2}{*}{$\begin{array}{c}\text { Mean } \pm \text { S.D } \\
\mathbf{n}=\mathbf{4} \\
>14.00 \mathrm{~g}\end{array}$} \\
\hline & & & $\begin{array}{c}\mathrm{n}=5 \\
<-210 \mathrm{~g}\end{array}$ & $\begin{array}{c}n=4 \\
211-300 g\end{array}$ & & $\begin{array}{c}\mathbf{n}=\mathbf{5} \\
<7.00 \mathrm{~g}\end{array}$ & $\begin{array}{c}\mathrm{n}=4 \\
7.00-4.00 \mathrm{~g}\end{array}$ & \\
\hline Hwt & $\begin{array}{r}232.88 \\
\pm 35.07\end{array}$ & $\begin{array}{r}250.60 \\
\pm 67.91\end{array}$ & $\begin{array}{l}201.87 \\
\pm 9.50\end{array}$ & $\begin{array}{l}174.74 \\
\pm 4.01\end{array}$ & $\begin{array}{r}239.75 \\
\pm 35.68\end{array}$ & $\begin{array}{c}359.49 \\
\pm 166.92\end{array}$ & $\begin{array}{c}217.99 \\
\pm 110.88\end{array}$ & $\begin{array}{l}295.11 \\
\pm 50.34\end{array}$ \\
\hline WBwt & $\begin{array}{l}11.52 \\
\pm 5.86\end{array}$ & $\begin{array}{l}11.88 \\
\pm 5.42\end{array}$ & $\begin{array}{c}7.92 \\
\pm 7.48\end{array}$ & $\begin{array}{l}10.60 \\
\pm 5.60\end{array}$ & $\begin{array}{l}11.31 \\
\pm 5.28\end{array}$ & $\begin{array}{c}16.51 \\
\pm 3.14\end{array}$ & $\begin{array}{c}5.15 \\
\pm 1.49\end{array}$ & $\begin{array}{l}17.19 \\
\pm 1.61\end{array}$ \\
\hline WBL & $\begin{array}{c}49.37 \\
\pm 21.71\end{array}$ & $\begin{aligned} & 52.47 \\
\pm & 22.51 \text { * }\end{aligned}$ & $\begin{array}{c}30.84 \\
\pm 23.01\end{array}$ & $\begin{array}{l}49.23 \\
\pm 8.87\end{array}$ & $\begin{array}{c}51.43 \\
\pm 22.53\end{array}$ & $\begin{array}{c}63.22 \\
\pm 15.40^{*}\end{array}$ & $\begin{array}{c}34.74 \\
\pm 13.99\end{array}$ & $\begin{array}{r}68.15 \\
\pm 8.38\end{array}$ \\
\hline $\mathrm{CBL}$ & $\begin{array}{c}42.70 \\
\pm 19.53\end{array}$ & $\begin{array}{c}45.25 \\
\pm 20.46^{*}\end{array}$ & $\begin{array}{c}26.93 \\
\pm 20.16\end{array}$ & $\begin{array}{l}41.70 \\
\pm 6.87\end{array}$ & $\begin{array}{c}45.60 \\
\pm 21.12\end{array}$ & $\begin{array}{c}54.07 \\
\pm 16.10 *\end{array}$ & $\begin{array}{r}12.17 \\
\pm 7.41\end{array}$ & $\begin{array}{r}42.90 \\
\pm 5.53\end{array}$ \\
\hline $\mathrm{CBD}$ & $\begin{aligned} & 3.65 \\
\pm & 23.50\end{aligned}$ & $\begin{aligned} & 43.66 \\
\pm & 22.16^{*}\end{aligned}$ & $\begin{array}{c}32.66 \\
\pm 32.58\end{array}$ & $\begin{array}{l}37.77 \\
\pm 4.69\end{array}$ & $\begin{array}{c}44.18 \\
\pm 20.18\end{array}$ & $\begin{array}{c}63.36 \\
\pm 28.05^{*}\end{array}$ & $\begin{array}{c}26.72 \\
\pm 12.12\end{array}$ & $\begin{array}{c}41.03 \\
\pm 10.08\end{array}$ \\
\hline $\mathrm{CBH}$ & $\begin{array}{c}30.48 \\
\pm 6.16\end{array}$ & $\begin{array}{c}30.31 \\
\pm 5.86\end{array}$ & $\begin{array}{r}30.86 \\
\pm 6.81\end{array}$ & $\begin{array}{c}25.58 \\
\pm 11.25\end{array}$ & $\begin{array}{c}42.03 \\
\pm 24.60 *\end{array}$ & $\begin{array}{c}33.97 \\
\pm 13.69\end{array}$ & $\begin{array}{l}21.28 \\
\pm 2.72\end{array}$ & $\begin{array}{l}29.77 \\
\pm 1.81\end{array}$ \\
\hline DOCB & $\begin{array}{l}1.81 \\
\pm 1.01\end{array}$ & $\begin{array}{c}2.02 \\
\pm 0.79 *\end{array}$ & $\begin{array}{c}1.31 \\
\pm 1.32\end{array}$ & $\begin{array}{c}37.34 \\
\pm 10.26\end{array}$ & $\begin{array}{c}52.03 \\
\pm 20.96\end{array}$ & $\begin{array}{c}60.77 \\
\pm 18.02 *\end{array}$ & $\begin{array}{c}38.29 \\
\pm 16.27\end{array}$ & $\begin{array}{c}50.02 \\
\pm 8.40\end{array}$ \\
\hline DUCB & $\begin{array}{c}2.39 \\
\pm 0.36\end{array}$ & $\begin{array}{c}2.38 \\
\pm 0.38\end{array}$ & $\begin{array}{c}2.40 \\
\pm 0.18\end{array}$ & $\begin{array}{l}62.00 \\
\pm 6.45\end{array}$ & $\begin{array}{l}44.07 \\
\pm 7.80\end{array}$ & $\begin{array}{c}52.42 \\
\pm 13.95^{*}\end{array}$ & $\begin{array}{r}31.10 \\
\pm 1.99\end{array}$ & $\begin{array}{c}51.58 \\
\pm 10.73\end{array}$ \\
\hline $\mathrm{CWt}$ & $\begin{array}{l}2.44 \\
\pm 0.40\end{array}$ & $\begin{array}{c}2.39 \\
\pm 0.39\end{array}$ & $\begin{array}{c}2.54 \\
\pm 0.39 *\end{array}$ & $\begin{array}{c}1.12 \\
\pm 0.86\end{array}$ & $\begin{array}{c}2.07 \\
\pm 1.29\end{array}$ & $\begin{array}{c}2.04 \\
\pm 1.22 *\end{array}$ & $\begin{array}{c}1.17 \\
\pm 0.92\end{array}$ & $\begin{array}{c}2.33 \\
\pm 0.80\end{array}$ \\
\hline $\mathrm{CH}$ & $\begin{array}{c}0.05 \\
\pm 0.02\end{array}$ & $\begin{array}{c}0.05 \\
\pm 0.02\end{array}$ & $\begin{array}{c}0.05 \\
\pm 0.02\end{array}$ & $\begin{array}{c}0.10 \\
\pm 0.24\end{array}$ & $\begin{array}{c}2.31 \\
\pm 0.29\end{array}$ & $\begin{array}{c}2.76 \\
\pm 0.32 \text { * }\end{array}$ & $\begin{array}{c}1.92 \\
\pm 0.07\end{array}$ & $\begin{array}{c}2.47 \\
\pm 0.14\end{array}$ \\
\hline $\mathrm{CD}$ & $\begin{array}{c}0.78 \\
\pm 0.25\end{array}$ & $\begin{array}{c}0.85 \\
\pm 0.04\end{array}$ & $\begin{array}{c}0.87 \\
\pm 0.02\end{array}$ & $\begin{array}{c}2.20 \\
\pm 0.36\end{array}$ & $\begin{array}{c}2.33 \\
\pm 0.41\end{array}$ & $\begin{array}{c}2.82 \\
\pm 0.29 *\end{array}$ & $\begin{array}{c}2.00 \\
\pm 0.03\end{array}$ & $\begin{array}{c}2.50 \\
\pm 0.49\end{array}$ \\
\hline WBwt/Hwt & $\begin{array}{c}0.05 \\
\pm 0.02\end{array}$ & $\begin{array}{c}0.05 \\
\pm 0.02 *\end{array}$ & $\begin{array}{c}0.05 \\
\pm 0.02\end{array}$ & $\begin{array}{c}0.07 \\
\pm 0.03\end{array}$ & $\begin{array}{c}0.05 \\
\pm 0.02\end{array}$ & $\begin{array}{c}0.04 \\
\pm 0.00\end{array}$ & $\begin{array}{c}0.02 \\
\pm 0.00\end{array}$ & $\begin{array}{c}0.05 \\
\pm 0.02\end{array}$ \\
\hline $\mathrm{CBL} / \mathrm{WBL}$ & $\begin{array}{c}0.86 \\
\pm 0.04 \\
\end{array}$ & $\begin{array}{r}0.85 \\
\pm 0.05\end{array}$ & $\begin{array}{c}0.87 \\
\pm 0.02 \\
\end{array}$ & $\begin{array}{c}0.85 \\
\pm 0.03\end{array}$ & $\begin{array}{c}0.88 \\
+0.03^{*}\end{array}$ & $\begin{array}{r}0.85 \\
\pm 0.05\end{array}$ & $\begin{array}{c}0.83 \\
\pm 0.02 \\
\end{array}$ & $\begin{array}{c}0.88 \\
\pm 0.03\end{array}$ \\
\hline
\end{tabular}

*significant values observed 


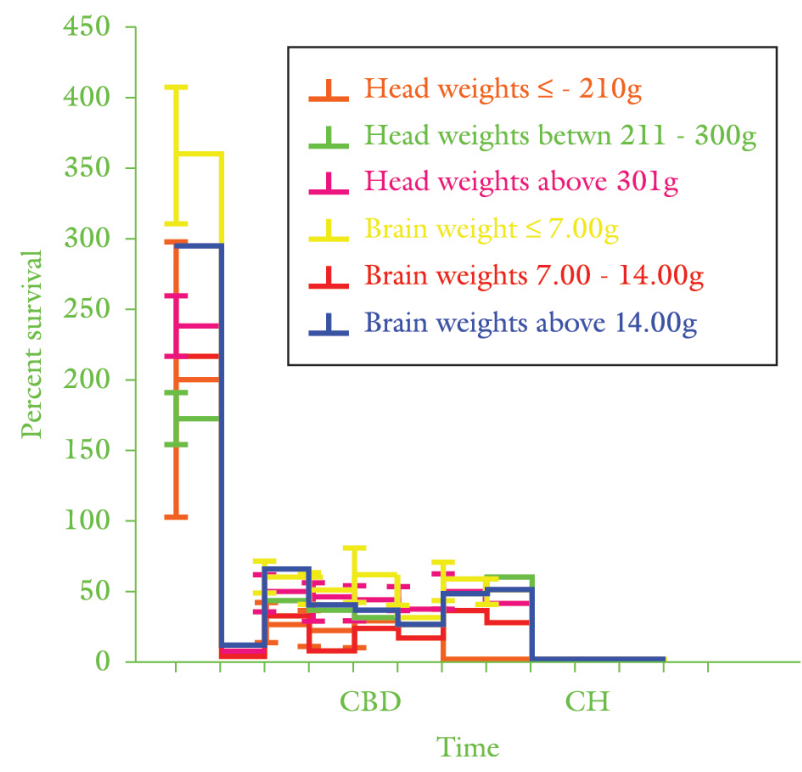

Figure 6. Kaplan-Meier survival graph showing the decrease in brain parameters magnitude among brain categories with increasing brain mass.

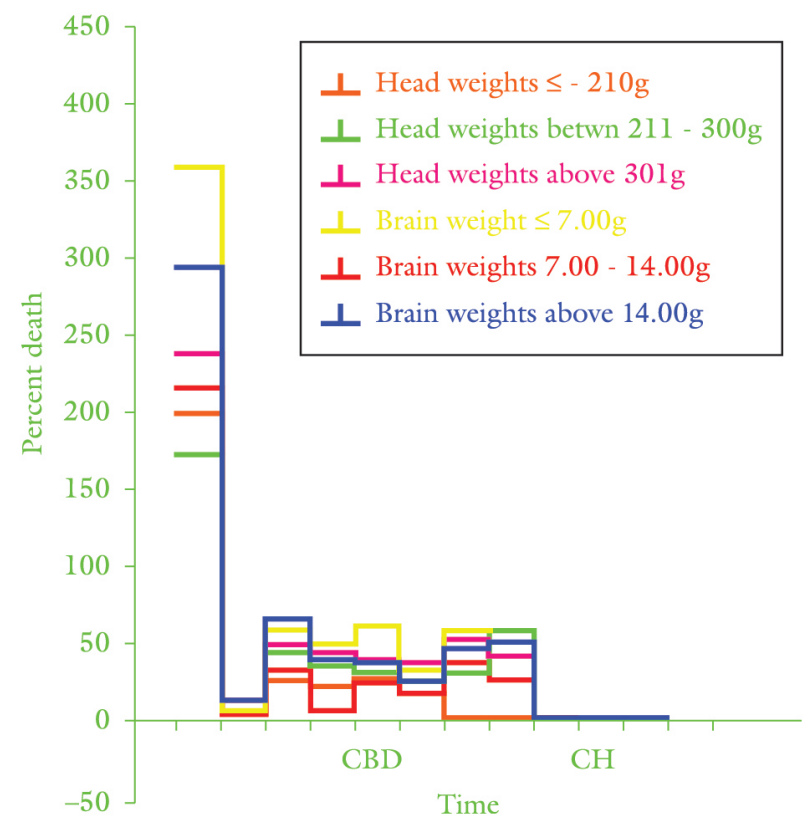

Figure 7. Composite Kaplan-Meier percentage death/ time graph of head and brain weight categories showing the percentage death rate among brain weight groups.

placed didelphimorphia in the most basal position, whereas all fruit eaters (alone or combined with other trophic roles) are more highly encephalized (STEPHAN and NELSON, 1998; SCHIEWE, 2010) revealing an independent evolution of intelligence within the same order (GERHARD and DICKE, $2005)$. It is also observed that encephalization quotient EQ increases with hemispheric length and mesencephalic cover in the Australian chiropterans Emballonuridae, Rhinolophidae and Hipposideridae (STEPHAN and NELSON, 1998). This is particularly so in the females of the present investigation.

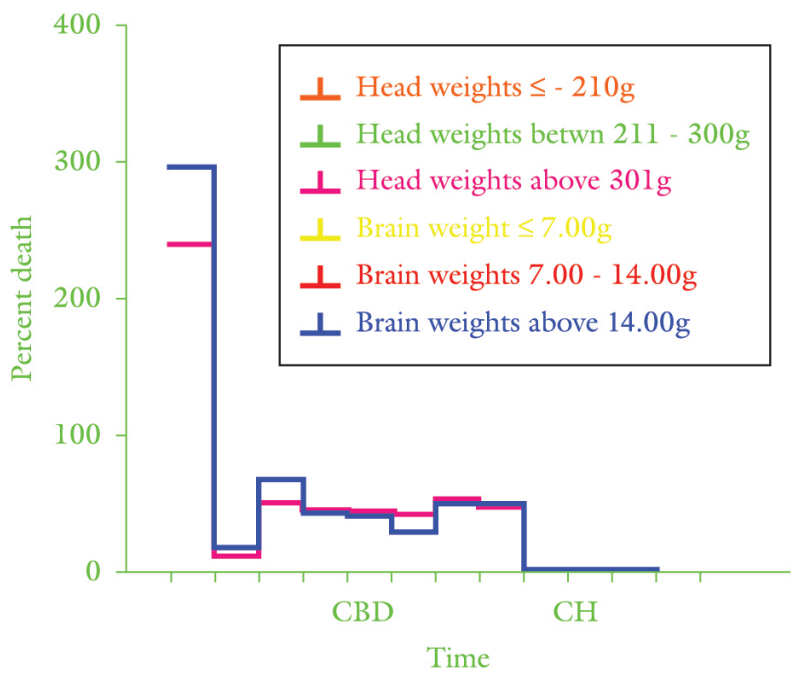

Figure 8. Percentage death/time curve of head weight (above $301 \mathrm{~g}$ ) and brain weight (above 14g) showing selected category graph with cerebellar diameter's early life reduction in size, prior to senile decline of lesser activity

Total brain weight comparison (Figure 6 ) between this species of didelphids, the kangaroo and other wildlife species of related size shows the averages as $30.43 \pm 10.19 \mathrm{~g}$ (brain length about $9.50 \mathrm{~cm}$ and body length $51 \mathrm{~cm}$ ), the cat $30 \mathrm{~g}$ (brain length $5 \mathrm{~cm}$ and body length $60 \mathrm{~cm}$ ), and the kangaroo $56 \mathrm{~g}$ (brain length $5 \mathrm{~cm}$ and body length $150 \mathrm{~cm}$ ) (NOWAK, 1999; SEMENDEFERI, ARMSTRONG, SCHLEICHER et al., 2002).

The resulting Neocorticalization, its attendant complementary increase in brain volume and a negative regression on other forebrain structural indices such as prefrontal and frontal cortex in the head weight categories attributed to the exponential brain growth function may be ecogenic and adaptive (HAUG, 1987; JERISON, 1997). This anatomic variations in the brain shape (prefrontal and frontal) relative to brain mass though not spectacular in size in other species (JERISON, 1997; SEMENDEFERI, ARMSTRONG, SCHLEICHER et al., 2002 ) as some types of members of this order has lesser relative neocortex than the rodentia, prosmians, carnivora and artiodactylia in the order (NOWAK, 1999). The results of interaction of the investigated parameters with brain categories represents about $78 \%$ and $20 \%$ of the variations respectively and is extremely significant at $\mathrm{P}<$ 0.0001 (Figure 7).

Scansorial or Arboreal preference is associated with a relatively large brain except in the case of Philander opossum. Among didelphid opossums those with relatively large cranial capacities are characterized by a relatively longer life span and lower litter sizes (EISENBERG and WILSON, 1981) corroborating the present evaluation of the possibility of a shorter life span/expectancy in the males of this species with smaller endocranial volumes (Figure 8 and 9). Ontogenic recapitulations of remote phylogenic characteristics in skull shape evolution of the didelphid opossum seems suspect within the limit of variations or diversity. 


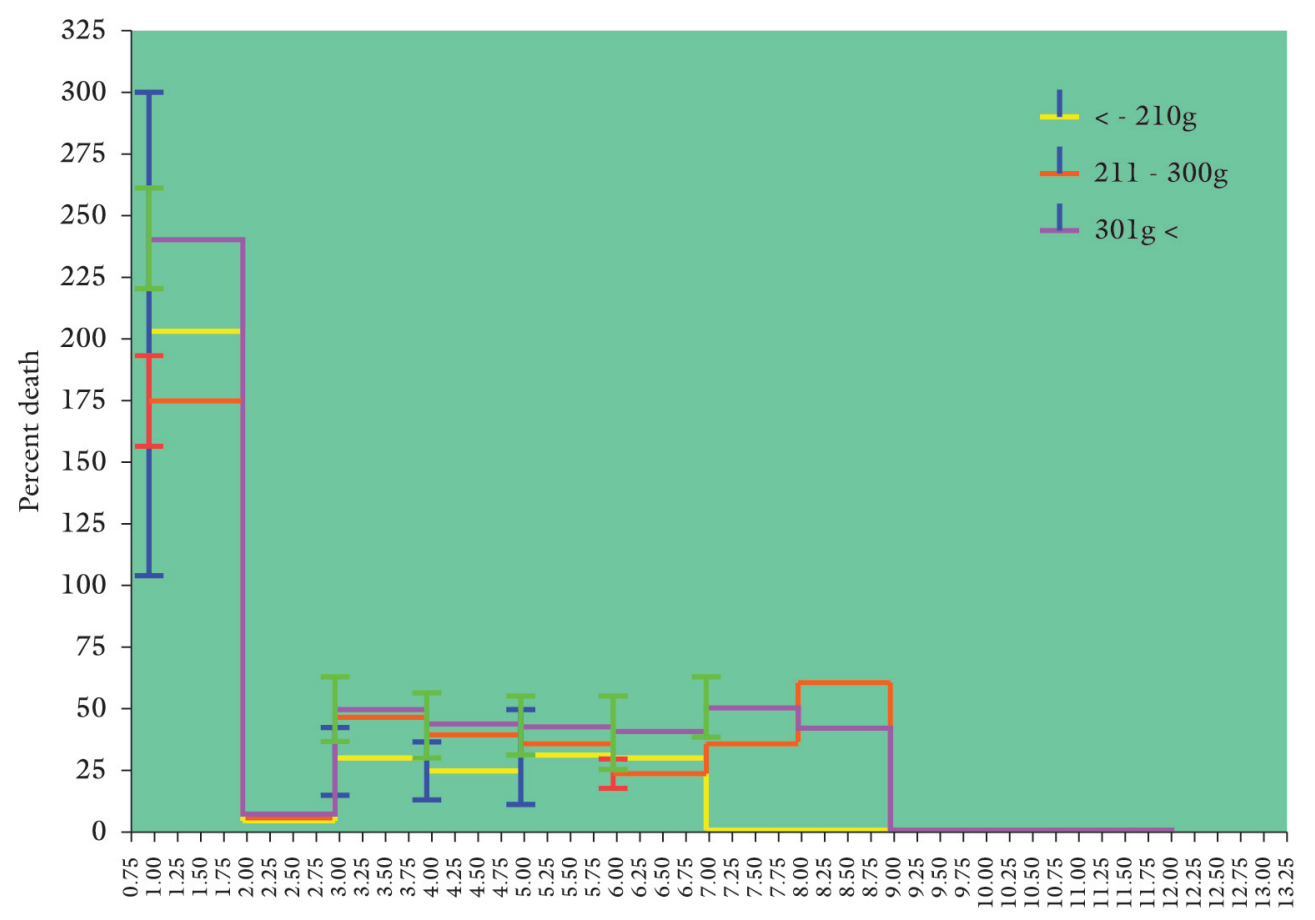

Time

Figure 9. Percentage death/time graph among head weight categories only; showing a markedly reduced population with time of the of head weight category $300 \mathrm{~g}$ and above.

\section{Conclusions}

Since the significance of anatomical data depends on the relation of structure to function, it appears that the Shortened premotor cortex within the smaller $\mathrm{CBH}$ group, an area responsible for learned or patterned skills and planning movements peaked within the brain weight category $211-300 \mathrm{~g}$. This value dropped off in the heaviest group, the association is suggestive of a reduced capacity for predation and competition in older animals and a reduced access to choice and adequate food. This observation is of consequence in wildlife management policy, population studies, species conservation process as well as a useful data for neurobiology research. The middle brain weight category bracket $(7-14 \mathrm{~g}$ ) of this species in a wildlife park, reserve or in captivity should be especially bio-tagged, trapped, medicated and fed for preservation in the process of species conservation.

\section{References}

ABE, A. Fundamental studies of animals of prehistoric Japan: estimation of the growth stage and body size of the wild boar (Sus Scrufa/Leucomyces) by observation and measurement of the crania. Anthrop Rep., 1989, vol. 48, p. 27-63.

AJAYI, S. Field observation on the African giant rat (Cricetomys gambianus) in South Nigeria, East Africa. Wildlife Journal, 1974, vol. 15, n. 3, p. 191-198.

ANDROUKAKI, E., FATAEA, E., HART, L., OSTERHAUS, ADME., TOUNTA, E. and KOTOMATAS, S. Growth and development of Mediterranean Monk Seal pups during rehabilitation. The Monachus Guardian, 2002, vol. 5, n. 1. Available from: <http://www.monachus-guardian.org>.
APLIN, KP. and ARCHER, N. Recent advances in Marsupials systematics with a new syncretic classification: possums and opossums studies in evolution. Chipping Norton: Surrey Beatty and Sons, 1987. p. 15-76. vol. 1.

GERHARD, R. and DICKE, U. Evolution of the brain and intelligence. Trends in Cognitive Sciences, 2005, vol. 9, n. 5, p. 250-257. PMid:15866152. http://dx.doi.org/10.1016/j. tics.2005.03.005

GIUliA, M., ZOTTI, A., AGNESSI, S., FIONNA, MGD. and COZZI, BB. Age classes and sex differences in the skull of the Mediterranean monk seal Monachus monachus (Herman, 1779): a study based on bone shape and density. Anatomical Records, 2009, vol. 292, p. 544-665. PMid:19301280. http://dx.doi. org/10.1002/ar.20876

GRAY, EE. Composition of the family Didelphidae (Didelphoides marsupialia) with a review of the morphology and behaviour of the included of the four-eyed pouched Opossum of the genus phylander Tiedermann, I philip Hershkovitz. Chicago: Field Museum of Natural History, 2009

HART, BL., HART, LA., MCCOY, M. and SARATH, CR. Cognitive behavior in Asian elephants: use and modification of branches for fly switching. Animal Behavior, 2007, vol. 62, n. 5, p. 839-847.

HAIER, RJ., JUNG, RE., YEO, RC., HEAD, K. and ALKIRED, MT. Structural brain variation and general intelligence. NeuroImage, 2004, vol. 23, n. 1, p. 425-433. PMid:15325390. http://dx.doi. org/10.1016/j.neuroimage.2004.04.025

HAUG, H. Brain sizes, surfaces, and neuronal sizes of the cortex cerebri: a stereological investigation of man and his variability and a comparison with some mammals (primates, whales, marsupials, insectivores, and one elephant). American Journal of Anatomy, 1987, vol. 180, n. 2, p. 126-142. PMid:3673918. http://dx.doi. org/10.1002/aja.1001800203 
HAPPOLD, D. C. D. Mammals of Nigeria. Oxford: Clarendon Press, 1987. p. 4-6.

JERISON, HJ. Evolution of the brain and intelligence. New York: Academic Press, 1973. p. 45.

JERISON, HJ. Evolution of prefrontal cortex. In KRASNEGOR, N., LYON, GR. and GOLDMAN-RAKIC, PS. (Eds). Development of the prefrontal cortex: evolution, neurobiology, and behavior. Baltimore: Brookes, 1997. p. 9-26.

EISENBERG, JF. and WILSON, DE. The American Naturalist, 1981, vol. 118, n. 1, p. 1-15. Available from: <http://www.jstor. org/stable/2460423>.

KHULENBECK, E. Overall brain size, and not encephalization quotient, best predicts cognitive ability across non-human primates. Brain, Behavior and Evolution, 2007, vol. 70, n. 2, p. 115-124. PMid:17510549. http://dx.doi.org/10.1159/000102973

LES, AL. and COCKBURN, A. Evolutionary ecology of marsupials. Cambridge: Cambridge University Press, 1985. p. 78-96.

MARSHAL, LG. Systematics of the South-American marsupial family caenolestidae. Chicago: Field Museum of Natural History, 1990.

NOWAK, RM. Walkers mammals of the world. 6th ed. Baltimore: The John Hopkins University Press, 1999.

OLOPADE, JO. Osteometric study of the skull of Red Sokoto (maradi) goats (Capra hircus) Implications for anaesthesia of the head. Ibadan: Department of Veterinary Amatomy, University of Ibadan, 2006. [Doctoral Thesis].
OLUDE, MA., OLOPADE, JO., FATOLA, IO. and ONWUKA, SK. Some aspects of the neurocraniometry of the African giant rat (Cricetomys gambianus Waterhouse). Folia Morphologica, 2009, vol. 68, n. 4, p. 224-227. Available from: <www.fm.viamedica.pl>.

SAMARANCH, R. and GONZALEZ, LM. Changes in morphology with age in the medittareanean monk seal (Monachus monachus). Marine Mammal Science, 2000, vol. 16, n. 1, p. 141-157. http:// dx.doi.org/10.1111/j.1748-7692.2000.tb00909.x

SCHIEWE, J. Australia's marsupials originated in what is now South America. Los Angeles Times, July 28, 2010.

SEMENDEFERI, K., ARMSTRONG, E., SCHLEICHER, A., ZILLES, K. and VAN HOESEN, GW. Humans and great apes share a large frontal cortex. Nature Neuroscience, 2002, vol. 5, n. 3, p. 272-276. PMid:11850633. http://dx.doi.org/10.1038/nn814

STEPHAN, H. and NELSON, JE. Brains of Australian Chiroptera I. Encephalization and macromorphology. Australian Journal of Zoology, 1998, vol. 29, n. 5, p. 663-670.

ZORILLINAB, E. Arrangement of families of mammals. 2008. 1094, 9074. Article 239, 251.

Received September 19, 2013 Accepted September 25, 2014 